\title{
Leadership Style, Competence and Job Satisfaction: Determinants of Performance
}

\author{
Ice Kamela M Mery Trianita \\ Fakultas Ekonomi dan Bisnis,Universitas Bung Hatta
}

\begin{abstract}
In tertiary institutions, the lecturer factor greatly determines the quality of education and is an important resource in educational services. Lecturers are an important component in improving the quality of education. In terms of academic development for students, lecturers have a strategic role in higher education. Based on professional considerations, lecturers are professionals who determine what is best for students. The quality of lecturers determines the development of the quality of education. The key factor that determines the strength of education is the lecturer. This study aims to examine the effect of the determinants of lecturer performance, namely leadership style, competence and job satisfaction. The number of samples in the study was 100 lecturers where the determination of the number of samples used the Slovin formula. Based on the test results found that competence has an effect on performance, leadership style and job satisfaction have no effect on performance.
\end{abstract}

Keywords: leadership style; competence; job satisfaction; performance

DOI: $10.7176 / \mathrm{JRDM} / 79-06$

Publication date:October $31^{\text {st }} 2021$

\section{INTRODUCTION}

In the context of human resource development, in the world of education, especially higher education, its strategic role is to prepare reliable human resources to answer global challenges. Higher education held in tertiary institutions initially carried out an essential function as a place for the enlightenment of human reasoning to take place. Higher education institutions must have a quality and quality learning process based on predetermined standards. The quality of the process and university graduates is determined by the quality of the academic programs they have, their human resources, facilities and infrastructure, and their academic atmosphere, which need to be improved in order to achieve national education standards.

In tertiary institutions, the lecturer factor greatly determines the quality of education and is an important resource in educational services in higher education. Lecturers are an important component in improving the quality of education. In terms of academic development for students, lecturers have a strategic role in higher education. Based on professional considerations, lecturers are professionals who determine what is best for students. The quality of lecturers determines the development of the quality of education. The key factor that determines the strength of education is the lecturer. Therefore, the education service industry is a "frontline provider and determine the quality of service delivery system", the quality of service is determined by the presence of lecturers at the forefront, (Sukmalana, 2010).

Law on Teachers and Lecturers Number 14 of 2005 from the Law of the Republic of Indonesia, states that, "Lecturers are professional educators and scientists with the main task of transforming, developing, and disseminating science, technology and art through education and teaching, research, and community service. Lecturers who are able to carry out the duties of the Tridarma of Higher Education well are lecturers who have good performance.

A preliminary survey conducted on universities that became the object of research, namely Bung Hatta University, revealed that of the 308 permanent lecturers who have functional teaching positions, 21 (7\%), Expert Assistants amounted to 94 people (31\%), 119 Lectors ( 38\%), Head Lectors 71 people (23\%) and Professors 3 people (1\%). This data explains that there are still many permanent lecturers who hold the position of Teaching Staff and Expert Assistants as much as 38\% and only 1\% have academic positions as Professors. When viewed from the level of education, only 82 people (27\%) have doctoral education. This explains that there is still a small number of permanent lecturers whose education is Strata-3 (S3). In addition, there are no funded student creativity program participants and only 1 person as an outstanding lecturer participant. The number of published scientific papers that have been published from research results and community service is also relatively low, this can be seen from LLDIKTI Region X information which explains that there is still low research and community service carried out by lecturers (Source: LLDIKTI Region X, 2018). The data revealed above shows that the performance of lecturers still needs to be improved.

Several studies related to lecturer performance have been carried out by several previous researchers. Leadership style has a significant effect on lecturer performance based on research results from (Rahmawati, $2011 b$ ). Furthermore, the results of other studies say that there is no influence of leadership on employee performance (Darto et al., 2015). Likewise, it was found that leadership was not significantly related to performance (Anwar et al., 2015). 
Characters, knowledge, skills, and abilities refer to competencies in each personal or individual character that can directly affect job performance for each individual. Competence has a significant direct effect on lecturer performance, which means that increasing lecturer competence will improve performance based on research results from (Sarmawa et al., 2015).

The results of another study found that job satisfaction is related to lecturer performance, and is positively correlated with a moderate level of closeness, which means that the higher the perceived job satisfaction, the higher the lecturer's performance according to research (Ika, O \& Weliyawati, 2015) While job satisfaction has no effect on performance based on research (Darto et al., 2015)

Research on the determinants of performance has been widely studied, including as previously discussed, but different research results were found from previous researchers (Research Gap). Based on the data and previous research, to prove the results of previous studies, the researchers conducted research again to strengthen the results of research that had been carried out previously.

The problem is how influence leadership style, competence and job satisfaction on lecturer performance?. So the purpose of this study is to prove and analyze the determinants of lecturer performance consisting of leadership style, lecturer competence and job satisfaction. It is hoped that from the findings of this study it will be possible to determine whether leadership style, competence and job satisfaction have an effect on lecturer performance.

\section{Literature Review and Hypothesis}

Development Performance Determinants Basically, performance is the result of work that can be achieved by an employee or group of employees in an organization, in accordance with their respective authorities and responsibilities, in an effort to achieve the goals of the organization concerned legally, not violating the law and in accordance with morals and ethics (Prawirosentono, 2008) ). Employee performance is influenced by 3 factors (Mangkunegara, 2009), namely: 1. Individual factors: Ability, mental skills, physical, family background, social level, experience. Age, ethnicity, gender 2. Organizational factors: resources, leadership, rewards, structure. 3. Psychological factors: perception, attitude, personality, learning, motivation. The three factors above will affect performance as the ultimate goal of the expected results. Leadership Style on Performance Leadership style is defined as the behavior shown by the leader in influencing subordinates. This behavior is influenced by several factors, such as: values, assumptions, perceptions, expectations, and attitudes that exist in the leader. Several studies on leadership style suggest that the leader's behavior in influencing subordinates will determine the effectiveness in leading. One leadership theory explains why someone succeeds in leading or influencing, while the other does not. A leader is said to be successful if he is able to carry out the leadership function well. Leadership style in an organizational environment including universities is a potential factor that directly or indirectly supports the achievement of employee or lecturer performance. (Wibowo, 2007) suggests that employee performance is influenced by leadership style, this can be seen from the working relationship with employees; providing rewards for employees who excel; develop and empower employees. All of this will affect employee performance. The results of the study (Sumardjoko, 2010), (Rahmawati, 2011a) found that leadership style had a significant effect on performance. These results do not support research (Anung Pramudyo, 2010), which states that leadership style has no significant effect on lecturer performance. The research hypotheses proposed are: H1: Leadership Style Affects Lecturer Performance The Effect of Competence on Performance Competence is a basic characteristic of a person that can be seen from the personality that influences behavior in dealing with work. In addition, competence is a combination of knowledge, skills, values and attitudes that are reflected in thoughts and actions. In the teaching system, competence is used to describe professional abilities, namely abilities, knowledge and conceptualization at a higher level. Competence can be obtained through education, training and experience. (Mulyasa, 2012) The teaching ability of lecturers is actually a reflection of the lecturers' competence. (Suparlan, 2006) explains that the standard of competence of lecturers is a measure that is determined in the form of mastery of knowledge and behavior of a lecturer to qualify for functional positions according to the field of duty, qualification and level of education. Several studies related to performance have been carried out by previous researchers, namely competence has a significant effect on performance. The results of the study found that competence has a positive effect on performance, this means that the higher the competence of the lecturer, the higher the performance (Sulindra, 2009) and (Setiawati, 2009). The hypothesis proposed in this study is H2. Competence affects Lecturer Performance the Effect of Job Satisfaction on Performance the high and low performance of lecturers is determined by the satisfaction felt by the lecturer at work. Optimal work results are obtained when someone feels satisfaction at work. The feeling of satisfaction felt at work when a person can complete the maximum task / work. Job satisfaction has a positive relationship with productivity or performance achievement, meaning that high job satisfaction will increase employee productivity or performance achievement. Work results have a relationship with job satisfaction where if an employee's work results increase it can have an impact on their perspective on the meaning of job satisfaction itself (Moh. As'ad, 2004). Several studies related to job satisfaction and performance have been studied by (Zami, 2008), and (Samtono, 2017), the results of his research found that job satisfaction has a positive and significant effect on lecturer performance. The proposed 
hypothesis is: H3: Job Satisfaction Affects Lecturer Performance Research Concept Framework Based on the description of the literature and previous research, the conceptual framework of the research can be seen in Figure

Figure1

Logical framework

Leadership Style

\section{RESEARCH METHODS}

Population and Sample

Before testing the hypothesis, it is necessary to determine the population and research sample. The research population referred to in this study were 308 permanent lecturers at Bung Hatta University. In this study, the Slovin formula is used to determine the population members to be taken as research samples. Based on the Slovin formula, the number of samples in this study was 100 lecturers

Data collection technique

This research uses survey method for primary data collection. Primary data as the main data used, namely data obtained from Bung Hatta University lecturers. Primary data collection using a questionnaire. Questionnaires were distributed to Bung Hatta University lecturers using Google forms and filled in directly by respondents in the hope that optimal results could be obtained in terms of returning the questionnaires. The questionnaires that have been collected will be checked before testing.

Operational Definition of Research Variables

The variables in this study consisted of three independent variables, namely: leadership style, competence and job satisfaction and 1 dependent variable, namely: Performance

Performance

Performance is the achievement of work by a lecturer on the task or work that is his responsibility according to the applicable standards in the scope of his duties or work. Lecturer performance was measured using a 5-point Likert scale with a range of strongly agree (5) to strongly disagree (1). Performance is measured through 3 dimensions, namely education \& teaching; study; and community service.

Job satisfaction

Job satisfaction is an attitude towards work or an emotional reaction of a lecturer in the form of feeling satisfied or dissatisfied with aspects of work. Job satisfaction was measured using a Likert scale with a range of very satisfied (5) to not very dissatisfied (1). Job satisfaction is measured through 3 dimensions of Income, Work Atmosphere and Rewards.

Leadership Style

Leadership style is the ability of a leader to influence his subordinates in completing a job to achieve a certain goal. Leadership style is measured using a 5-point Likert scale with a range of strongly agree (5) to strongly disagree (1). Leadership style is measured through dimensions: task behavior, relationship behavior, readiness/maturity in carrying out tasks.

Lecturer Competence

Competence is a person's ability to work, have the skills, knowledge and expertise and professionals used in carrying out an activity.

Competence in this study was measured using a 5-point Likert scale with a range of strongly agree (5) to strongly disagree (1). Competence is measured through Dimensions: Personality, Pedagogic, Professional, and Social.

Instrument Testing

Validity test

Validity test shows the extent to which a measuring instrument actually measures what it wants to measure. Corrected item total correlation is used to determine whether or not a statement item is valid.

Reliability Test

Reliability test shows the extent to which a measuring instrument can be relied upon when repeated measurements are made. Measurement. A construct or variable is said to be reliable if the Cronbach's Alpha value $>0.60$.

Data analysis technique

The hypothesis proposed in this study will be proven by using multiple linear regression analysis. Multiple linear regression was used to examine the effect of leadership style, competence and job satisfaction on performance. 
The regression equation of this study is:

$$
\begin{aligned}
& Y=a+b_{1} X_{1}+b_{2} X_{2}+b_{3} X_{3} \\
& Y=\text { Performance } \\
& X_{1}=\text { Leadership style } \\
& X_{2}=\text { competence } \\
& X_{3}=\text { Job satisfaction }
\end{aligned}
$$

\begin{tabular}{|c|c|c|c|}
\hline & & & \\
\hline NO. & & & Total \\
\hline \multirow{2}{*}{1.} & \multirow[t]{2}{*}{ Gender } & Male & 35 \\
\hline & & Female & 65 \\
\hline \multirow{4}{*}{2.} & \multirow{4}{*}{ Ages } & $25-30$ & 10 \\
\hline & & $31-40$ & 45 \\
\hline & & $41-50$ & 30 \\
\hline & & $51-60$ & 15 \\
\hline \multirow{6}{*}{3.} & \multirow{3}{*}{ Education $\mathrm{r}$} & (S1) & - \\
\hline & & (S2) & 85 \\
\hline & & (S3) & 15 \\
\hline & \multirow{3}{*}{ Academic position } & Asisten Ahli & 15 \\
\hline & & Lektor & 45 \\
\hline & & Lektor Kepala & 25 \\
\hline
\end{tabular}

\section{RESULTS AND DISCUSSION}

Demographic Characteristics of Respondents who participated in this study can be seen in the following table

Table 1

Characteristic Responders

Sumber: Data primer yang Diolah 2020

Based on the characteristics of the respondents in table 1, most of the Bung Hatta University lecturers who became respondents were dominated by female lecturers with a total of 65 people $(65 \%)$ with a productive age range of 31-40 years as many as 45 people (45\%), educated the last S2 with a total of 85 people (85\%) and the lecturer with a Lecturer Academic Position as many as 45 people (45\%). From the data above, it can be concluded that the profession as a lecturer is more in demand by women, with a productive age range, S2 education level, because to become a lecturer a minimum education is required to have a master's degree and the academic position is already Lecturer.

Validity Test Results

The results of the validity testing that have been carried out, then the summary of the test results for each variable can be seen in table 2 below

Table 2

Validity Test

\begin{tabular}{|l|c|c|c|}
\hline \multicolumn{1}{|c|}{ Variable } & $\begin{array}{c}\text { Corrected Item Total } \\
\text { Correlation }\end{array}$ & Cut Off & \\
\hline Leadership style & $0.541-0,529$ & 0,5 & Valid \\
\hline Competency & $0.614-0.699$ & 0.5 & Valid \\
\hline Job satisfaction & $0,556-0,655$ & 0,5 & Valid \\
\hline Performance & $0,572-0,633$ & 0,5 & Valid \\
\hline
\end{tabular}

Sumber : Data primer yang diolah 2020

Table 2 shows the corrected item total correlation values generated for all variables in the range above 0.50 . So it can be concluded that the statement items used to measure the variables of leadership style, competence, job satisfaction and performance are valid and can be tested further.

Reliability Test Results

To test the reliability of the variable using the Cronbach alpha value. If the Cronbach alpha value 0.6 then the variable is said to be reliable. From the data in table 3, it can be seen that each research variable consisting of leadership style, competence, job satisfaction and performance has a Cronbach alpha value above 0.6. So it can be concluded that all variables are declared reliable. 
Table 3

Reliability Test

\begin{tabular}{|l|c|c|c|}
\hline \multicolumn{1}{|c|}{ Variable } & Cronbach Alpha & Cut Off & \\
\hline Leadership style & 0,670 & 0,6 & Reliable \\
\hline Competency & 0,742 & 0,6 & Reliable \\
\hline Job satisfaction & 0,752 & 0,6 & Reliable \\
\hline Performance & 0,654 & 0,6 & Reliable \\
\hline
\end{tabular}

Sumber : Data primer yang diolah 2020

Results of Multiple Linear Regression Analysis and Discussion of Research Results

The results of hypothesis testing in this study using multiple linear regression analysis can be seen in table 4 . Of the three hypotheses proposed, only one variable has a significant effect on lecturer performance, namely the competency variable. While the variables of leadership style and job satisfaction have no effect on performance.

Table 4

Hypothesis Test

\begin{tabular}{|l|c|c|l|}
\hline \multicolumn{1}{|c|}{ Variable } & Coefficient Regression & P-Value & \multicolumn{1}{c|}{ Hypothesis } \\
\hline (constant) & 4,505 & & \\
\hline Leadership style X1) & 0,29 & 0,061 & $\mathrm{H}_{1}$ not accepted \\
\hline Competency (X2) & 0,31 & 0,000 & $\mathrm{H}_{2}$ accepted \\
\hline Job satisfaction (X3) & 0,16 & 0,365 & $\mathrm{H}_{3}$ not accepted \\
\hline
\end{tabular}

Sumber : Data primer yang diolah 2020

Based on the table above, the multiple linear regression equation model is obtained as follows:

$$
\mathrm{Y}=4,505+0,29 \mathrm{X}_{1}+0,31 \mathrm{X}_{2}+0,16 \mathrm{X}_{3}+\mathrm{e}
$$

The Influence of Leadership Style on Lecturer Performance

After processing the data, the result is that the regression coefficient value of leadership style is 0.29 and has a significance value of 0.06 where the significance value is greater than 0.05 . This shows that leadership style has no effect on lecturer performance. So it can be concluded that the first hypothesis (H1) in this study is rejected, meaning that leadership style has no effect on lecturer performance. However, the applied leadership style will not affect the lecturer's performance. The significance of leadership style on lecturer performance is because the perceived leadership style with task behaviour by lecturers has not been able to improve lecturer performance.

The results of this study support research conducted by (Anwar et al., 2015) which states that leadership style has no significant effect on performance and research conducted by (Anung Pramudyo, 2010), which states that leadership style has no significant effect on lecturer performance. However, the results of this study contradict the results of research (Sumardjoko, 2010), and (Rahmawati, 2011a) found that leadership style has an effect on performance.

The Effect of Competence on Performance

After processing the data, the result of the regression coefficient value of lecturer competence is 0.31 and has a significance value of 0.00 where the value is smaller than 0.05 so that it can be concluded that the hypothesis (H2) which states that competence affects the performance of lecturers is accepted. Owned by lecturers (pedagogy, professional, social and personality will affect performance. The results of this study support research (Rina \& Kusuma, 2017) and (Sahito \& Vaisanen, 2017) which in general both state that competence has a significant effect on performance.

The results of this study support the theory which states that competence is a combination of knowledge, skills, values and attitudes that are reflected in the habits of thinking and acting. This competence can grow well so as to improve performance, especially in terms of social competence, namely being able to communicate and interact with students. Thus the implication is that performance can be improved if the management pays attention to competence, especially social competence in terms of the ability to communicate with students.

The Effect of Job Satisfaction on Lecturer Performance

The results of this study indicate that the value of the regression coefficient of job satisfaction on lecturer performance is 0.16 and is not statistically significant because the significance value of 0.365 is greater than 0.05 so that the third hypothesis (H3) proposed is rejected. The results of the study found that job satisfaction had no significant effect on performance. This is in line with the results of research (Darto et al., 2015) which states that job satisfaction has no effect on performance. The results of this study do not support several studies related to job satisfaction and performance (Zami, 2008), and (Samtono, 2017), the results of his research found that Job Satisfaction had a positive and significant effect on Lecturer Performance

The high and low performance of lecturers is determined by the satisfaction felt by the lecturer at work. Optimal work results are obtained when someone feels satisfaction at work. The feeling of satisfaction felt at work when a person can complete the maximum task / work. 


\section{CONCLUSION}

This research was conducted with the aim of examining the effect of leadership style, competence and job satisfaction on lecturer performance. Based on the results of the tests that have been carried out, the hypotheses proposed in this study, not all of them are proven. The determinant of performance is only competence that has a positive effect on performance performance, while leadership style and job satisfaction are not proven to affect performance. Competencies as measured by personality, pedagogic, professional and social competencies can improve performance. Therefore, in order to improve the performance of lecturers, the university management should focus more on improving the competence of lecturers, especially social competence in terms of the ability of lecturers to communicate.

Research Limitations

Limitations in this study are the number and wide range of objects that are used as units of analysis to become respondents. The results of this study can be generalized if the unit of analysis is expanded to include all private universities in West Sumatra with more respondents.

Research Recommendations

1. For future research, the object of research is recommended not only to measure the performance of lecturers/employees but also the performance of the organization.

2. Data collection is not only through questionnaires, but also through interviews, so that the research results are more perfect

3. The independent variables are not limited to the three variables of leadership style, job satisfaction and competence, but can be added with other variables that also affect performance such as OCB, motivation, organizational commitment and others.

\section{ACKNOWLEDGMENTS.}

The author would like to thank the Chancellor and Director of LPPM Bung Hatta University who have supported the author to conduct research. The same words to the lecturers who participated in this study.

\section{Bilbiografy}

Anung Pramudyo. (2010). Analisis Faktor-Faktor Yang Mempengaruhi Kinerja Dosen Negeri Pada Kopertis Wilayah V Yogyakart. Jurnal Bisnis Teori Dan Implementasi, Vol.1 No.1(9), 1689-1699. https://doi.org/10.1017/CBO9781107415324.004

Anwar, A. A., Maupa, H., Haerani, S., \& Pahlevi, C. (2015). The Effects of Leadership Styles, Organizational Climate, Environmental Aspects and Organizational Commitment and Job Satisfaction on the Lectures ' Performance of Kopertis III in Jakarta. Scientific Research Journal (SCIRJ), III(Ix), 37-42.

Darto, M., Setyadi, D., Riadi, S. S., \& Hariyadi, S. (2015). The Effect of Transformational Leadership , Religiosity , Job Satisfaction, and Organizational Culture on Organizational Citizenship Behavior and Employee Performance in the Regional Offices of National Institute of Public Administration, Republic of In. European Journal of Business and Management, 7(23), 205-219.

Mangkunegara, A. P. (2009). Manajemen Sumber Daya Manusia. PT. Remaja Rosdakarya.

Moh.As'ad. (2004). Psikologi Industri. Liberty.

Mulyasa, E. (2012). Kurikulum Berbasis Kompetensi. Konsep, Karakteristik, dan Implementasi. PT Remaja Rosdakarya.

Prawirosentono, S. (2008). Kebijakan Kinerja Karyawan. BPFE Universitas Gaah Mada.

Rahmawati. (2011a). Pengaruh Budaya Organisasi, Gaya Kepemimpinan, dan Motivasi Kerja Terhadap Kinerja Dosen Di Universitas Sultan Ageng Tirtayasa. Jurnal Aplikasi Manajemen,2(1).

Rahmawati. (2011b). Pengaruh Budaya Organisasi, Gaya Kepemimpinan, Dan Motivasi Kerja Terhadap Kinerja Dosen Di Universitas Sultan Ageng Tirtayasa. Jurnal Administrasi Publik, Vol.2 No.1.

Rina, \& Kusuma, A. H. P. (2017). Pengaruh kompetensi, budaya organisasi dan motivasi terhadap kinerja dosen perguruan tinggi swasta di kota makassar. Jurnal Riset Edisi XIX, 3(008), 88-100.

Sahito, Z., \& Vaisanen, P. (2017). Effect of ICT Skills on the Job Satisfaction of Teacher Educators: Evidence from the Universities of the Sindh Province of Pakistan. International Journal of Higher Education, 6(4), 122. https://doi.org/10.5430/ijhe.v6n4p122

Samtono. (2017). Pengaruh Lingkungan Kerja Dan Kepuasan Kerja Terhadap Kinerja Dimediasi Motivasi Kerja Pada Guru- Guru Smk Ma’arif Comal Pemalang. Jurna Among Makarti, 10(20), 95-113.

Sarmawa, I., Suryani, N., \& Riana, I. G. (2015). Commitment And Competency As An Organizational Citizenship Behaviour Predictor And Its Effect On The Performance a Study of Private Vocational High Schools in Klungkung Regency, Bali, Indonesia. International Journal of Economics, Commerce and Management United, III (1), 1-13.

Setiawati, T. (2009). Pengaruh Kompetensi Kerja Terhadap Kinerja Dosen (Studi Kasus Di FPTK UPI). Jurnal Media Pendidikan, Gizi Dan Kuliner, 1(1). 
Sukmalana, S. (2010). Perencanaan SDM. PT. Intermedia Personalia Utama.

Sulindra, I. G. M. (2009). Kompetensi Kepribadian Dosen Berdasarkan Penilaian Persepsional. Media Bina Ilmiah.

Sumardjoko, B. (2010). Faktor-Faktor Determinan Peran Dosen Dalam Penjaminan Mutu Perguruan Tinggi. Jurnal Cakrawala Pendidikan, 3(3), 294-310. https://doi.org/10.21831/cp.v3i3.359

Suparlan. (2006). Guru Sebagai Profesi. Hikayat Publishing.

Wibowo. (2007). Manajemen Kinerja. PT.Raja Grafindo Persada.

Zami, A. (2008). Pengaruh Budaya Kerja dan Komitmen Dosen Terhadap Kepuasan Kerja Serta Implikasinya Pada Kinerja Dosen Tetap (Suatu Studi Pada Program Studi Magister Manajemen Di DKI Jakarta. UPI Y.A.I, Jakarta. 